\title{
Modelling of different enzyme productions by solid-state fermentation on several agro-industrial residues
}

DOI:

10.1007/s00253-016-7629-y

\section{Document Version}

Accepted author manuscript

Link to publication record in Manchester Research Explorer

\section{Citation for published version (APA):}

Diaz Sanchez, A. B., Blandino, A., Webb, C., \& Caro, I. (2016). Modelling of different enzyme productions by solidstate fermentation on several agro-industrial residues. Applied microbiology and biotechnology, 100(22), 95559566. https://doi.org/10.1007/s00253-016-7629-y

\section{Published in:}

Applied microbiology and biotechnology

\section{Citing this paper}

Please note that where the full-text provided on Manchester Research Explorer is the Author Accepted Manuscript or Proof version this may differ from the final Published version. If citing, it is advised that you check and use the publisher's definitive version.

\section{General rights}

Copyright and moral rights for the publications made accessible in the Research Explorer are retained by the authors and/or other copyright owners and it is a condition of accessing publications that users recognise and abide by the legal requirements associated with these rights.

\section{Takedown policy}

If you believe that this document breaches copyright please refer to the University of Manchester's Takedown Procedures [http://man.ac.uk/04Y6Bo] or contact uml.scholarlycommunications@manchester.ac.uk providing relevant details, so we can investigate your claim.

\section{OPEN ACCESS}




\title{
Modelling of different enzymes production by solid state fermentation on several agro-industrial
} residues

\author{
Ana Belen Diaz ${ }^{\mathrm{a}, *}$, Ana Blandino ${ }^{\mathrm{b}}$, Colin Webb c and Ildefonso Caro b \\ ${ }^{a}$ Laboratory of Microbiology, Faculty of Marine and Environmental Sciences, University of Cádiz, Pol. \\ Río San Pedro s/n, Puerto Real, Spain \\ b Department of Chemical Engineering and Food Technology, Faculty of Sciences, International Agro- \\ Food Campus of Excellence (CeiA3), University of Cádiz, Pol. Río San Pedro s/n, Puerto Real, Spain. \\ c Department of Chemical Engineering, School of Chemical Engineering \& Analytical Science. University \\ of Manchester, C77, The Mill, Oxford Road, Manchester, M13 9PL, United Kingdom.
}

\begin{abstract}
A simple kinetic model, with only three fitting parameters, for several enzymes production in Petri dishes by solid state fermentation is proposed in this paper, which may be a valuable tool for simulation of this type of processes. Basically, the model is able to predict temporal fungal enzymes production by solid state fermentation on complex substrates, maximum enzyme activity expected and time at which these maximums are reached. In this work several fermentations in solid state were performed in Petri dishes, using four filamentous fungi grown on different agro-industrial residues, measuring xylanase, exopoligalacturonase, cellulose and laccase activities over time. Regression coefficients after fitting experimental data to the proposed model turned out to be quite high in all cases. In fact, these results are very interesting considering on the one hand, the simplicity of the model, and on the other hand, that enzyme activities correspond to different enzymes, produced by different fungi on different substrates.
\end{abstract}

Keywords: kinetic, enzymes, solid state fermentation, agro-industrial residues.

\section{Introduction}

Recently, there has been an increasing trend towards more efficient utilization of agro-industrial byproducts for conversion to a range of value-added bio-products (Pandey et al. 2000). In general, large volumes of solid wastes, residues and by-products are generated throughout the year as a consequence of agricultural and agro-food industries, produced either in the primary agro-forestry sector or by secondary processing industries. For this reason, the bioprocessing of these residues, which have attracted considerable attention for being abundantly available and cheap, can help solve environmental problems associated with their disposal (Koopmans and Koppejan 1997). As a result, an extensive range of valuable and usable products can be recovered from what was previously considered waste.

The development of efficient processes, with potential to add value to these agro-industrial residues becomes one of the biggest challenges in biotechnology today. Several processes have been recently developed to utilize these raw materials for the production of bulk chemicals and value-added fine

* Corresponding author at: Department of Chemical Engineering and Food 

Pandey 1996).

Solid state fermentation (SSF) is a complex heterogeneous three-phase (gas-liquid-solid) fermentation, which shows a special relevancy in the field of biotechnological processes. In general, it is defined as the growth of microorganisms, often fungi, on the surface of a porous and moist solid substrate particle in which enough moisture is present to maintain microbial growth and metabolism. This process is carried out in absence or near-absence of visible liquid water between the particles. This condition favours the development of filamentous fungi, given their unique capacity to colonize the interparticular spaces of solid matrices (Ruíz-Leza 2004).

SSF shows several advantages compared to submerged fermentation (SmF) such as higher titers of enzyme production employing fungal cultures (Singhania et al., 2009). As far as enzyme cost is concern, Kumar et al. (2011) demonstrated that both techniques are equally cost-effective when pectinase and cellulase were produced using agro industrial wastes as substrate. However, lipase production through SSF by Penicillium restrictum turned out to be more economically feasible (Biz et al., 2016). According to an economic analysis carried out by Castilho et al. (2000) it was possible to reduce total capital investment in a 78\%, for a production scale of $100 \mathrm{~m} 3$ lipase concentrated per annum, by using SSF technique. Another advantage associated to SSF is the low catabolite repression, which seems to limit enzyme production in SmF processes (Cadirci et al., 2016). Furthermore, fermented solid after SSF can be dried and directly added for the hydrolysis process, eliminating the steps of recovery and enzymes concentration (Fernandes et al., 2007).

On the contrary, SSF processes are slower due to the barrier from the bulk solid. Furthermore, heat transfer is reduced in SSF as a consequence of inter and intraparticle resistance, resulting a difficult control, especially in continuous operations (Raghavarao et al., 2016). Moreover, agglomerated of substrate particles might be formed in SSF at large scale, leading to overheating some parts of the bed and, consequently, lack of uniformity in enzyme production within the bed (Biz et al., 2016).

Several types of equipments are used for SSF processes at laboratory scale. One interesting reactor, used by Raimbault and Germon (1976), was composed of aerated small glass columns filled with a previously inoculated solid, which were placed in a thermoregulated water-bath (Durand, 2003). Giving the geometry of the columns, it was easy to maintain the temperature in the reactors. Regulation of water content during the process might be improved in this configuration with the introduction of a relative humidity probe, a cooling coil on the air circuit and a heating cover for the vessel. As regards agitated bioreactor, several configurations are used: rotating drum, perforated drum or, with more efficient mixing, horizontal paddle. However, as a consequence of mycelium growth, agglomerates of substrate particles are formed in all these reactors, being mixing less efficient and, consequently, temperature controls is more difficult.

Agro-industrial residues are generally considered the best substrate for SSF processes. Given their composition, rich in sugars such us cellulose, hemicellulose and pectin, they can be easily assimilated by 
microorganisms (Rodriguez-Couto 2008). In fact, SSF has emerged as an appropriate technology for the management of agro-industrial residues and to provide added value to these materials (Orzua et al. 2009). This is the case, for example, of the production of microbial enzymes by the fermentation of those wastes (Romo 2015).

Our research group has previously found that Aspergillus awamori can produce efficiently hydrolytic enzymes, which include cellulases, xylanases and pectinases by SSF using as medium of fermentation several agro-industrial residues widely available in Spain such as grape pomace, orange peels or tomato pomace (Díaz et al. 2011; Umsza-Guez et al. 2011). In this work we also explore the utilization of two other lignocellulosic residues -rice husk and wheat straw- for the production of those enzymes by the following filamentous fungi: Botryotinia fuckeliana (anamorph Botrytis cinerea Pers.), Trichoderma reesei and Phanerochaete crysosporium. The potential of Trichoderma species as lignocellulose-degrading agents was recognized in the early 1960s and specifically Trichoderma reesei is a microorganism with a high capacity for lignocellulosic material degradation (Motta and Santana 2014).

Botrytis cinerea is a pathogenic filamentous fungus, which infects more than 200 plant species in a variety of organs including fruit, flowers, and leaves. For this, it secretes a battery of enzymes utilized for the degradation and consumption of the host plant. Pectin degradation is enabled by pectinases (Shah et al. 2009) and cutinolytic and cellulolytic activity have also been reported for cutin and cellulose breakdown respectively (Kapat et al. 1998). Finally, Phanerochaete chrysosporium has been selected for this study due to its efficiency in lignin degradation (Shi et al. 2014).

When those filamentous fungi grow on solid substrates form a mycelium i.e. a dense interconnected network of tubes called hyphae. Therefore, assessing biomass content is very complicated because it is almost impossible to separate the fungus from its solid substrate. Therefore, the fungal growth cannot be directly estimated as dry biomass. Instead, the rate of substrate colonization can be determined by indirect methods such as ergosterol content, levels of enzyme or $\mathrm{N}$-acetyl-D-glucosamine production (Barreto et al. 2011). In this work a modified method of the one reported by Ruíz et al. has been used. It consists on the determination of the microorganism growth rate in Petri dishes by measuring radial growth on a homogenous blend of particle size distribution of the solid substrate (Ruíz et al. 2012).

Due to the complexity of fungus growth on natural solid substrates and the subsequent spatial and temporal heterogeneity of environment, it is very difficult to investigate SSF processes by experimental methods alone. Mathematical modelling is now proving to be a very powerful and successful complementary tool (Barreto et al. 2011). This work describes an attempt to mathematically formulate the production of several enzymes by filamentous fungi processes in Petri dishes by SSF. The complex behaviour of different enzymes production employing agro-industrial residues as substrate has been previously modelled and reported in literature (Hashemi et al. 2011; Mazutti et al. 2010; RodriguezFernandez et al. 2011; Shi et al. 2012). Thus, in this paper a kinetic model for several enzymes production in Petri dishes is proposed, which shows as main advantage its simplicity and, therefore, the possibility of being a useful tool for simulation and development of this kind of processes. 


\section{Material and methods}

For the kinetic study, the activities of the hydrolytic enzymes cellulase, xylanase, exo-polygalacturonase and laccase were measured after solid state fermentation of Aspergillus awamori, isolated from bran (CECT 2907), Trichoderma reesei, isolated from cotton duck shelter (CECT 2414), Botryotinia fuckeliana, isolated from rotten grape (CECT 20518), and Phanerochaete chrysosporium, isolated from fruit and petiole of Vitis vinifera (CECT 2798) on grape pomace, orange peels, rice husk and wheat straw. These strains were provided by the Spanish Type Culture Collection (CECT).

\section{Spore production}

Fungi were propagated at $25^{\circ} \mathrm{C}$ for 5 days on petri dishes containing a synthetic medium for fungal growth composed of (g/L): 1 peptone, 0.5 yeast extract, 15 agar, 6 xylan and 1 pectin. This medium contains xylan and pectin as sole carbon sources to induce the production of xylanase and exopolygalacturonase. Spores were counted in an Improved Neubauer Counting Chamber and stored on 30 $\%$ glycerol at $-30^{\circ} \mathrm{C}$ and used for all experiments. As Phanerochaete chrysosporium showed difficulties to sporulate, the inoculation protocol followed was different. In this case, in the centre of the petri dish with the synthetic medium, a piece of agar with mycelium was placed. All the strains used are classified as GRAS (Generally Regarded As Safe).

\section{Conditioning of solid substrates}

As it has been previously mentioned, four agro-industrial residues were used as solid substrate of fermentation.

White grape pomace from Xerez, Sheres-Sherry area in Spain of the Palomino Fino variety was collected from a local wine cellar after pressing the aforementioned grape variety and stored at $-20^{\circ} \mathrm{C}$ before use. For fermentations, sub-samples ( $250 \mathrm{~g}$ ) were taken and defrosted at room temperature. Solid was dried in an oven $\left(60^{\circ} \mathrm{C}\right.$ for $\left.48 \mathrm{~h}\right)$, milled and sieved selecting particles over $1 \mathrm{~mm}$ of diameter. Next, it was washed several times with distilled water to minimize the high reducing sugars content, and dried again.

Orange peels (Washington Navel variety) were obtained after juice extraction from oranges collected at a local market and stored at $-20^{\circ} \mathrm{C}$. For SSF experiments, they were defrosted, milled and extensively washed in order to remove all water soluble compounds. The solid was dried at $60{ }^{\circ} \mathrm{C}$ for $48 \mathrm{~h}$. Solid particles were sieved selecting those over $1 \mathrm{~mm}$.

Rice hulls were provided by the Spanish company Herba Ricemills. The residue was first milled, sieved to collect the fraction of $0.2-1 \mathrm{~mm}$ and stored at room temperature until use. As regards wheat straw, it was provided by IFAPA center Rancho de la Merced (Jerez, Spain) and treated as rice hulls.

\section{Solid state fermentation}

Fermentations were carried out with $5 \mathrm{~g}$ of sterilized solid substrate (autoclaved at $120^{\circ} \mathrm{C}, 1.2 \mathrm{~atm}$ and 20 min) in static conditions at $25{ }^{\circ} \mathrm{C}$. Inoculums concentration was adjusted to $1.0 \cdot 10^{7}$ spores. The required amount of spore suspension and the exact amount of nutrient solution at $\mathrm{pH} 5.0$, containing $(\mathrm{g} / \mathrm{L}) 2.4$ 
urea, $9.8 \mathrm{~g}\left(\mathrm{NH}_{4}\right)_{2} \mathrm{SO}_{4}, 5.0 \mathrm{KH}_{2} \mathrm{PO}_{4}, 0.001 \mathrm{FeSO}_{4} \cdot 7 \mathrm{H}_{2} \mathrm{O}, 0.0008 \mathrm{ZnSO}_{4} \cdot 7 \mathrm{H}_{2} \mathrm{O}, 0.004 \mathrm{MgSO}_{4} \cdot 7 \mathrm{H}_{2} \mathrm{O}$ and $0.001 \mathrm{CuSO}_{4} \cdot 5 \mathrm{H}_{2} \mathrm{O}$, to obtain an initial moisture content of $70 \%$ were poured into disposable Petri dishes ( $9 \mathrm{~cm}$ diameter). Moreover, this solution supplemented with $11.5 \mathrm{~g} / \mathrm{L}$ of pectin to induce the production of pectinases was used for grape pomace (Díaz et al. 2012). Every experiment was developed in duplicate.

\section{Extraction conditions}

After fermentation, the content of each Petri dish was transferred into Erlenmeyer flasks containing 35 $\mathrm{mL}$ of Tween $80(0.1 \%, \mathrm{v} / \mathrm{v})$ and then stirred in a rotary shaker $\left(150 \mathrm{rpm}, 30 \mathrm{~min}, 4^{\circ} \mathrm{C}\right)$. These conditions of extraction were optimized in a previous work (Díaz et al. 2007). Suspensions resulting after the extraction were centrifuged at $10,000 \mathrm{rpm}$ for $10 \mathrm{~min}$ at $4^{\circ} \mathrm{C}$. Supernatants obtained, the enzymatic extracts, were stored at $-20^{\circ} \mathrm{C}$ until required for analysis.

\section{Ensymes assays}

Enzymatic activities of xylanase (EC 3.2.1.8), exo-PG (Exopolygalacturonase, EC 3.2.1.67), CMC-ase (carboxymethyl cellulase, EC 3.2.1.4) and laccase (EC 1.10.3.2)in the extracts obtained after fermentations were analysed. For xylanase, the reaction mixture containing $0.1 \mathrm{~mL}$ of enzymatic extract and $0.9 \mathrm{~mL}$ of xylan suspension $\left(0.5 \%\right.$, w/w, Birchwood xylan in $0.05 \mathrm{M}$ citrate buffer, $\mathrm{pH}$ 5.4) was incubated at $50{ }^{\circ} \mathrm{C}$ for $10 \mathrm{~min}$. The reducing sugars produced were measured by a modification of the dinitrosalicylic acid method (DNS) using D-xylose as the standard (Miller 1959). CMC-ase activity was determined by the same procedure described for xylanase, but carboxymethyl-cellulose (Panreac) was used as substrate. ExoPG activity was evaluated by adding $0.2 \mathrm{~mL}$ of enzymatic extract to $0.8 \mathrm{~mL}$ pectin solution $(0.5 \%$ pectin in $0.1 \mathrm{M}$ acetate buffer, $\mathrm{pH}$ 5.0). Samples were incubated at $45^{\circ} \mathrm{C}$ for $10 \mathrm{~min}$ and the reducing groups in the enzymatic extract were determined by the DNS (3,5-Dinitrosalicylic acid) method.

All the measurements were made in duplicate and the results expressed as reducing sugars using a calibration curve.

A unit of enzyme activity $(\mathrm{U})$ was defined as the amount of enzyme producing $1 \mu \mathrm{mol}$ of reducing sugars per minute at the specified conditions.

Laccase activity was determined by oxidation of ABTS (2,2'azino-bis(3-ethylbenzthiazoline-6-sulfonate)). The assay mixture contained $300 \mu \mathrm{L}$ ABTS $(10 \mathrm{mM}), 1200 \mu \mathrm{L}$ of sodium acetate $(50 \mathrm{mM}, \mathrm{pH} 4.5)$ and $1200 \mu \mathrm{L}$ of water and was kept at $30^{\circ} \mathrm{C}$ for $10 \mathrm{~min}$. Then, $300 \mu \mathrm{L}$ of the enzyme extract were added and incubated for $10 \mathrm{~min}$. The mixture was placed on ice immediately to stop the reaction. Oxidation of ABTS was monitored by determining the increase of absorbance at $420 \mathrm{~nm}$.

A unit of laccase activity $(U)$ was defined as the amount of enzyme which oxidises $1 \mu$ mol of ABTS per minute at $30^{\circ} \mathrm{C}$.

\section{Biomass monitoring}


Biomass during fermentations was monitored by an indirect procedure, which turned out to be simple and quick (Ruiz et al. 2012). Basically, the method consists on measuring the degree of colonization of the solid substrate with mycelium in every moment. For this purpose, diameter of the circle formed on the surface of the solid bed was measured. Thus, the colonized surface versus time was calculated, which is directly related to the amount of biomass in the dish. This method was slightly modified due to the colonized surface did not have always a perfect spherical geometry. So, pictures of the plates were taken at different times throughout the process and analyzed by image analysis software (Motic Images Plus 2.0). Results can be obtained directly as values of colonized area versus time and, with the proper correlation, data of biomass concentration (expressed as mg dry biomass/g dry solid) could be available.

\section{Kinetic model}

The proposed kinetic model is based on the analysis performed from the experiments carried out for this work and on previous observations reported in the literature.

On the one hand it is detected that the production of enzymes by solid state fermentation on Petri dishes usually shows a first phase in which enzyme activity rises and reaches a maximum and on the other hand, a decrease in the enzyme activity is observed afterwards (Mazutti et al. 2010). This behaviour is typically due to the existence of two successive processes in these conditions: the production of the enzyme and its inactivation. As for all series reactions, the relative rates of both reactions determine the instant at which the maximal concentration of intermediate product (active form of the enzyme) is reached (Levenspiel 1972).

In general, the enzyme precursor $(\mathrm{R})$ is converted into the active form of the enzyme (E) by action of the microorganisms, and this last form becomes denatured spontaneously to the inactive form of the enzyme (I) afterwards.

\section{$\stackrel{1}{1} \underset{2}{2} I$}

Thus, as the initial phase of the enzyme production curve has an analogous profile than the microorganism growth one, the first stage in which enzyme is synthesized by the microorganisms (step 1) is essentially growth-associated. It must be considered that several enzymes are precisely synthesized and secreted to the solid medium by the microorganism in order to digest the substrate and to colonize medium (Mazutti et al. 2010). On the other hand, other authors have proposed non-growth associated models (Favela-Torres et al. 1998) or combined models for enzymes production, including both growth and non-growth associated terms. However, in most cases the non-growth associated terms are negligible along most the fermentation process (Shi et al. 2014). Moreover, the majority of these complex models include many fitting parameters and the resulting kinetic equations may be difficult to solve. As a consequence, in this paper it is proposed a simple and growth-associated model for the rate of enzyme production, which includes a proportionality constant $\mathrm{k}_{\mathrm{E}}$.

$$
\left(\frac{\mathrm{dE}}{\mathrm{dt}}\right)_{1}=\mathrm{k}_{\mathrm{E}} \frac{\mathrm{dx}}{\mathrm{dt}}
$$


For the second stage, in which the inactivation of the active enzyme occurs (step 2) it is proposed a first order kinetic, with a kinetic constant $\mathrm{k}_{\mathrm{D}}$. As it is well-known, this is the most simple and generally accepted model for spontaneous inactivation of enzymes (Bailey and Ollis 1986)

$$
\left(\frac{\mathrm{dE}}{\mathrm{dt}}\right)_{2}=\mathbf{k}_{\mathrm{D}} \mathbf{E}
$$

Keeping in mind both stages, the following kinetic equation can be used to describe the active enzyme production during solid state fermentation and the evolution of the enzymatic activity of the extracts obtained:

$$
\frac{d E}{d t}=\left(\frac{d E}{d t}\right)_{1}+\left(\frac{d E}{d t}\right)_{2}=k_{E} \frac{d x}{d t}-k_{D} E
$$

On the other hand, the most generally accepted model to describe fungal growth during solid state fermentation is the logistic one (Bailey and Ollis 1986). As it is well-known, the logistic model describes microbial growth based on the following mathematical expression:

$\frac{\mathrm{dx}}{\mathrm{dt}}=\mu \mathrm{x}\left(1-\frac{\mathrm{x}}{\mathrm{x}_{\mathrm{m}}}\right)$

Where $\mathrm{X}$ represents instantaneous fungal biomass concentration and $\mathrm{X}_{\mathrm{m}}$ the maximum biomass concentration, which is reached when the whole solid substrate has been colonized by the fungus; moment at which the fungal growth ceases. The parameter $\mu$ represents the specific microbial growth rate at the specific conditions at which fermentation was carried out. The integration of this equation leads to the following widely used kinetic expression:

$$
X=\frac{X_{m}}{1+\left(\frac{X_{m}}{X_{o}}-1\right) e^{-\mu t}}
$$

where $\mathrm{X}_{\mathrm{o}}$ represents the biomass inoculated at time $\mathrm{t}=0$.

Definitively, once initial and final fungal biomass concentrations in the culture medium $\left(\mathrm{X}_{\mathrm{o}}\right.$ and $\left.\mathrm{X}_{\mathrm{m}}\right)$ are known, the proposed simple kinetic model includes only three parameters to be determined: the specific microbial growth rate at the specific conditions of fermentation $(\mu)$; the specific enzyme productivity by the fungus at the fermentation conditions $\left(\mathrm{k}_{\mathrm{E}}\right)$; and the denaturation kinetic constant at the fermentation conditions $\left(\mathrm{k}_{\mathrm{D}}\right)$.

$$
\frac{d E}{d t}+k_{D} E=k_{E} \mu x\left(1-\frac{x}{x_{m}}\right)
$$

This equation has the advantage of dealing with only a few parameters. However, as a drawback it does not consider the influence of some variables, which are also very important in solid state fermentation processes. Some of these variables are, for example, solid particle size, package density of the solid bed, or the activity level of the inoculum. Indeed, it should be considered that once we have established the value of $\mu$, it is defined the inoculum activity level and all the others variables that influence on this parameter, such as the oxygen availability to biomass. The last variable is, at the same time, influenced by solid particle size and bed package density. 
Thus, in this model, the influence of all the process variables is condensed definitely into three parameters.

Given that we set the same process conditions at the optimal values, many process conditions are fixed and, as a result, the values of the three parameters depend only on a few of them. So, for example, in this work we have always used the same particle size and package density, thus, in this case, the values of $\mu$ will only depend on the microorganism.

As regards the mathematical features of the model, the proposed kinetic equation (7) has no simple analytical solution in a way that an exact value of the active enzyme concentration for a specific time could be known. Nevertheless, if the initial and final fungal biomass concentrations in the culture medium $\left(X_{\circ}\right.$ and $\left.\mathrm{X}_{\mathrm{m}}\right)$ are known, and for the three given values of the kinetic parameters $\left(\mu, \mathrm{k}_{\mathrm{E}}\right.$ and $\left.\mathrm{k}_{\mathrm{D}}\right)$, it is possible to integrate numerically the differential equation and to obtain $\mathrm{E}$ values for any time. For the integration of the differential equation any of the recommended numerical procedures for this type of equations, as Runge-Kutta or analogous to this one, can be used (Gupta 1995).

In this work several experiments have been carried out under very different conditions and from them various data of enzymatic activity (E) versus time ( $\mathrm{t}$ ) have been obtained. Subsequently, by using the recommended mathematical methods of nonlinear regression for these cases (Motulsky and Christopoulos 2004), the values of the kinetic parameters of the equation have been calculated in a way that the difference between both, experimental and theoretical values of $\mathrm{E}$, is minimum. In order to solve numerically the differential equation of the model, the algorithm of Runge-Kutta $4^{\text {th }}$ order has been used. It has been implemented a calculus routine in the MATLAB ${ }^{\circledR}$ software, which usually takes less than thirty seconds to reach the best values of the equation parameters introducing a set of experimental data. The regression coefficient $\left(\mathrm{R}^{2}\right)$ in a set of experimental values has been computed as:

$$
R^{2}=1-\frac{\sum_{i=1}^{n}\left(E_{\text {exp-i}}-E_{t e o-i}\right)^{2}}{\sum_{i=1}^{n}\left(E_{\text {exp }-i}-\frac{\sum_{i=1}^{n} E_{\text {exp-i }}}{n}\right)^{2}}
$$

Where $\mathrm{E}_{\text {exp-i }}$ is any experimental value of the active enzyme concentration in a set; $\mathrm{E}_{\text {teo-i }}$ is the theoretical value corresponding to the experimental value of the active enzyme concentration in a set, both at the same time; and $\mathrm{n}$ is the total number of experimental (or theoretical) data in a set.

\section{Results}

First of all, after following the experimental protocol previously described, the evolution of enzyme activities over time was represented. It is important to point out that all possible combinations fungus/substrate selected for this study were tested, although no growth and, therefore, no enzyme production were detected in some cases. In the cases which enzyme production was measured, data were expressed as E, this is units of enzyme activity (U) per kilogram of dry solid. 
In Figure 1 (A, B and C), some of the enzyme production kinetics obtained in this study are represented fermentation follows the typical profile trend previously described; this is a first phase of activity increase and, after a maximum, a decrease is observed as a consequence of its inactivation. Consequently, from this evidence, experimental data have been all fit to the mathematical model proposed in this paper. In this respect, they have been taken as values of initial biomass concentration $\left(\mathrm{X}_{\mathrm{o}}\right)$ and maximum biomass $\left(\mathrm{X}_{\mathrm{m}}\right)$, the corresponding average values of all fermentations performed. Initial biomass concentration on the plates was calculated from the number of spores inoculated, their average size and density, and the initial mass of solid substrate, giving a mean value of $\mathrm{X}_{\mathrm{o}}=2.4 \mathrm{mg}$ biomass / $\mathrm{g}$ solid (both in dry weight). On the other hand, maximum final biomass concentration in the plates was calculated from the total solid colonized by mycelium, its average density and the initial mass of solid substrate, giving a mean value of $\mathrm{X}_{\mathrm{m}}=63.6 \mathrm{mg}$ biomass $/ \mathrm{g}$ solid (both in dry weight).

Table 1 shows regression coefficient $\left(\mathrm{R}^{2}\right)$ after fitting experimental data to the proposed model. As can be seen, regression coefficient turned out to be quite high in all cases $(>0.9)$ and the average general regression coefficient was 0.949 .

\section{Specific microbial growth rate}

As regards specific growth rate $(\mu)$, results obtained after fitting are shown in Table 2 . The fungus / substrate combinations not included in this Table correspond to situations in which no growth was detected, thus the established value of $\mu$ in this model would be zero.

The lowest growth rate observed correspond to Botryotinia fuckeliana on orange peels, with an average specific growth rate around $20 \cdot 10^{-3} \mathrm{~h}^{-1}$. On the other hand, the fastest growth was detected for Trichoderma reesei and Aspergillus awamori on orange peels, with an average growth rate of $55 \cdot 10^{-3}$ and $49 \cdot 10^{-3} \mathrm{~h}^{-1}$, respectively.

It can be observed that average specific growth rates calculated with different substrates are very similar. So, the average specific growth rate on grape pomace was $37 \cdot 10^{-3} \mathrm{~h}^{-1}$, whereas the values $39 \cdot 10^{-3} \mathrm{~h}^{-1}$, $38 \cdot 10^{-3} \mathrm{~h}^{-1}, 37 \cdot 10^{-3} \mathrm{~h}^{-1}$ and $40 \cdot 10^{-3} \mathrm{~h}^{-1}$ were obtained for supplemented grape pomace, orange peels, rice husk and wheat straw, respectively.

Finally, the average specific growth rate for Trichoderma reesei is around $45 \cdot 10^{-3} \mathrm{~h}^{-1}$, value calculated from data of Table 2. For Aspergillus awamori, Botryotinia fuckeliana and Phanerochaete crysosporium, these values were $39 \cdot 10^{-3} \mathrm{~h}^{-1}, 35 \cdot 10^{-3} \mathrm{~h}^{-1}$ and $30 \cdot 10^{-3} \mathrm{~h}^{-1}$, respectively.

\section{Ensyme inactivation constant}

Table 3 shows the inactivation constants of the different studied enzymes $\left(k_{\mathrm{D}}\right)$. As can be seen, these values remain low in all cases (between 0 and $5 \cdot 10^{-3} \mathrm{~h}^{-1}$ ), except in two cases. 
As for comparative analysis of the different enzymes, xylanase from Aspergillus awamori is the most

$\mathrm{h}^{-1}$ was calculated for exo-PG from Trichoderma reesei on rice husk and for laccase from Botryotinia fuckelinana on the same substrate. These data suggest that certain products obtained in the hydrolysis of this type of substrates could inactivate some of the enzymes.

Negligible deactivation constants resulted for xylanase and cellulase from Botryotinia fuckeliana, xylanase and cellulase from Trichoderma reesei and the enzymes from Phanerochaete crysosporium in the studied conditions.

\section{Ensyme production constant}

As can be seen in Figure 2, values resulted for the third parameter of the model, enzyme production constant $\left(\mathrm{k}_{\mathrm{E}}\right)$, are very variable. Thus, in some cases low enzyme productivities were obtained, such as laccase from Botryotinia fuckeliana on wheat straw and grape pomace, with only $2 \mathrm{U} / \mathrm{g}$ of dry solid and 10 $\mathrm{U} / \mathrm{g}$ of dry solid, respectively. On the contrary, xylanase from the same microorganism on wheat straw produced $1189 \mathrm{U} / \mathrm{g}$ of dry solid.

Clearly, it can be seen in Figure 2 that Botryotinia fuckeliana grown in wheat straw turned out to be the best producer of most studied enzymes but laccase, with a total productivity of $2058 \mathrm{U} / \mathrm{g}$ of dry solid. However, total productivity of the same enzyme from Trichoderma reesei on the same substrate was the lowest measured, with $216 \mathrm{U} / \mathrm{g}$ of dry solid. These data reflect that the microorganism is much more decisive in the evolution of solid state fermentation than the substrate.

Finally, orange peels are shown to be the most versatile among the studied substrates with more than 1200 $\mathrm{U} / \mathrm{g}$ dry solid with Phanerochaete crysosporium and about $1000 \mathrm{U} / \mathrm{g}$ dry solid wih Trichoderma reseei and Aspergillus awamori.

\section{Time of maximum enzyme activity}

As a main feature of the analyzed kinetic behavior, it can be mentioned the existence of a maximum enzyme activity during the fermentation process in the conditions studied. In fact, this maximum is the consequence of the production and simultaneous inactivation of the enzymes and it is detected at a given time, which generally is different for each enzyme in the fermentation process. So, from a practical point of view, prior enzyme extraction, the determination of that type of maxima is of paramount importance due to the possibility of controlling the fermentation cycles. In this sense, from equations of the proposed kinetic model, and once the values of the kinetic parameters for each case are known, it is possible to approach the numerical calculation of the evolution of different enzyme activities over time $\mathrm{E}(\mathrm{t})$. Therefore, it can be also calculated the instant at which maximum enzyme activities are attained and their value $\left(\mathrm{E}_{\mathrm{m}}\right)$. Table 4 shows times at which these maximum activities were reached in the studied conditions.

As shown, times of maximum enzyme activity do not coincide in most cases. For example, when Trichoderma resee $i$ is grown on orange peels, maximum xylanase activity is detected around $94 \mathrm{~h}$ of fermentation. However, maximum cellulose and exo-polygalacturonase activities are observed at $229 \mathrm{~h}$ 
and after $360 \mathrm{~h}$, respectively. Similarly, when Botryotinia fuckeliana grew on grape pomace, maximum laccase activitiy is detected around $86 \mathrm{~h}$ of fermentation, while exo-polygalacturonase after $188 \mathrm{~h}$. Regarding xylanase or cellulose, maximum is detected after $360 \mathrm{~h}$.

\section{Direct calculation of maximum ensyme activity}

The determination of maximum enzyme activity by numerical methods is tedious and does not allow handling of simple equations to optimize industrial processes. For this reason, it may be of interest to address the calculation of these maxima by maximum mathematical analysis. Unfortunately, given the complex resulting equation after integrating the proposed model, it is not possible to obtain this result accurately. However, it is possible to carry out fairly approximate calculation with simple equations as follows.

According to the proposed model, where $t_{m}$ is the moment of maximum enzyme activity, $E_{m}$ its value at that instant, and $\mathrm{X}_{\mathrm{E}}$ biomass concentration at that moment, it can be set that at the time where maximum is attained, following expressions are true:

$\mathrm{dE} / \mathrm{dt}=0$

$\mathrm{k}_{\mathrm{D}} \mathrm{E}_{\mathrm{m}}=\mathrm{k}_{\mathrm{E}} \mu \mathrm{X}_{\mathrm{E}}\left(1-\frac{\mathrm{X}_{\mathrm{E}}}{\mathrm{X}_{\mathrm{m}}}\right)$

$\mathrm{E}_{\mathrm{m}}=\frac{\mathrm{k}_{\mathrm{E}} \mu}{\mathrm{k}_{\mathrm{D}}} \mathrm{X}_{\mathrm{E}}\left(1-\frac{\mathrm{X}_{\mathrm{E}}}{\mathrm{X}_{\mathrm{m}}}\right)$

Integrated form of $\mathrm{X}(\mathrm{t})$ is available, but not for $\mathrm{E}(\mathrm{t})$, therefore, it is not possible to solve for the exact value of $\mathrm{t}_{\mathrm{m}}$ from above equation. However, it is possible to develop an expression to get $\mathrm{X}_{\mathrm{E}}$ and then from it, the value of $t_{m}$ from integrated expression of $X(t)$,

For $\mathrm{X}_{\mathrm{E}}$ calculation, firstly it should be considered the following. Being $t_{\mathrm{x}}$ the moment when biomass concentration is in the inflection point, according to the logistic model, that instant can be exactly calculated as follows:

$\frac{\mathrm{dx}}{\mathrm{dt}}=\mu \mathrm{x}\left(1-\frac{\mathrm{x}}{\mathrm{x}_{\mathrm{m}}}\right)$

$\frac{\mathrm{d}^{2} \mathrm{X}}{\mathrm{dt}^{2}}=0$

$0=\mu\left(1-2 \frac{\mathrm{X}_{\mathrm{x}}}{\mathrm{X}_{\mathrm{m}}}\right)$

$\mathrm{X}_{\mathrm{x}}=\frac{\mathrm{X}_{\mathrm{m}}}{2}$

Substituting this value in the integrated equation $\mathrm{X}(\mathrm{t})$ and solving for the value of $\mathrm{t}_{\mathrm{x}}$, the following expression is obtained.

$\mathbf{t}_{\mathbf{x}}=\frac{\ln \left(\frac{\mathbf{X}_{\mathbf{m}}}{\mathbf{X}_{\mathrm{o}}}-\mathbf{1}\right)}{\boldsymbol{\mu}}$ 
Secondly, from the mathematical form, which shows the solution of the differential equation of the proposed model $\mathrm{E}(\mathrm{t})$, including hypergeometric series, it can be deduced that this function can be expressed as an infinite terms polynomial of reduced variable $\left(\mathrm{X} / \mathrm{X}_{\mathrm{m}}\right)$, whose coefficients are also infinite series. All these series include the dimensionless factor $\left(\mathrm{k}_{\mathrm{D}} / \mu\right)$ in various degrees. Thus, by deriving the expression of $\mathrm{E}(\mathrm{t})$ with respect to time and equating to zero, an expression for the ratio $\mathrm{X}_{\mathrm{E}} / \mathrm{X}_{\mathrm{m}}$ can be obtained. This expression is also a combination of infinite series, but making certain approximations thereof, it is possible to get an approximate value of $\mathrm{X}_{\mathrm{E}} / \mathrm{X}_{\mathrm{m}}$ with enough precision:

$\emptyset=\frac{1}{1+\frac{k_{D}}{\mu}}$

$\frac{\mathrm{X}_{\mathrm{E}}}{\mathrm{X}_{\mathrm{m}}} \approx \frac{3+\emptyset+\emptyset^{2}+\emptyset^{3}}{6}$

Finally, after obtaining the value of $\mathrm{X}_{\mathrm{E}}$, it is possible to solve for the value of $\mathrm{t}_{\mathrm{m}}$ from the logistic model as follows:

$\mathbf{t}_{m}=\frac{1}{\mu} \cdot \ln \left(\frac{\frac{\mathrm{X}_{\mathrm{E}}}{\mathrm{X}_{\mathrm{o}}}}{1-\frac{\mathrm{X}_{\mathrm{E}}}{\mathrm{X}_{\mathrm{m}}}}\right)$

As can be seen, biomass inflection point $\left(t_{\mathrm{x}}\right)$ only depends on the values of $\mu$ and biomass initial and final values $\left(\mathrm{X}_{\mathrm{o}}, \mathrm{X}_{\mathrm{m}}\right)$. This fact is due to biomass growth has been assumed independent of enzyme production and, in any case, its influence would be included within the value of $\mu$. However, the time of maximum activity for each enzyme $\left(t_{m}\right)$ is also affected by the value of the inactivation constant of such enzyme $\left(\mathrm{k}_{\mathrm{D}}\right)$, since inactivation intensity affects the maximum value. Finally, it can be observed that enzyme productivity constant $\left(\mathrm{k}_{\mathrm{E}}\right)$ does not affect the maximum value $\left(\mathrm{t}_{\mathrm{m}}\right)$, but does affect the activity value at that moment, as shown in the equation previously deduced for $\mathrm{E}_{\mathrm{m}}$.

\section{Discussion}

In this paper it is proposed a simple kinetic model, which predicts fungal enzymes production over time by SSF on complex substrates on Petri dishes, thus, the time of maximum enzyme activity can be determined. The experimental data of enzyme activity, measured for various enzymes secreted by four filamentous fungi grown on different agro-industrial residues, fit the model with very high regression coefficients. Moreover, the defined kinetic parameters and the analysis allow establishing the end of fermentation, or time at which maximum enzymatic activities are reached. This information is very valuable for scale up and improvement of this kind of processes in these conditions.

The mean value of maximum final biomass concentration in the plates calculated in this work is within the range of values reported in literature for other solid state fermentations in lab scale. However, it should be considered that the specific value in each case depends significantly on temperature, moisture content of the bed, aeration and other operating variables of the process, which might be different to those used in this study (do Santos et al. 2003, Roche and Durand 1996; Roopesh et al. 2006). 
Regression coefficients $\left(\mathrm{R}^{2}\right)$ shown in Table 1 after fitting experimental data to the proposed model turned out to be quite high in all cases. Thus, proposed equations justify the $95 \%$ of the observed variability in the data of enzyme activity. This result is quite interesting, considering the simplicity of the mathematical model proposed and given that experimental data came from very different processes, those are different enzymes, fungi and substrates. So, it can be seen that the model shows great dynamism and plasticity, despite its apparent rigidity due to it has only three parameters to fit. In this way, it is possible to fit successfully the kinetic profile of all fermentations studied based on the values of $\mu, \mathrm{k}_{\mathrm{E}}$ and $\mathrm{k}_{\mathrm{D}}$. As regards specific rate of growth $(\mu)$ (Table 2), their values remain within the expected range for fungal growth by SSF (between 10 and 90·10-3 h-1) (Favela-Torres et al. 1998; Ruiz et al. 2012; Smits et al. 1996). Furthermore, there is good data consistency among results from different cases. So, for example, the values of specific growth rates obtained for a given microorganism in a particular substrate should be similar, regardless the enzyme used for the values calculated. Moreover, a good data consistency between different cases remains. According to the proposed model, this situation is the logical consequence given that all enzymes produced in the same fermentation process, should lead to the same specific rate for that process. However, given the high variability of biological processes, important dispersions can be found in the results since small differences in the initial conditions of each plate can cause big differences in the evolution of the fermentation process. Interestingly, both the fastest and slowest growth were obtained with the same substrate (orange peels), which shows that growth rate is much more determined by the type of microorganism than the type of substrate where it grows. In fact, once guaranteed sources of carbon and other nutrients needed for cell replication, the specific growth rate of each species should be given by their metabolic profile and, definitely, by their genetic profile.

Average specific growth rates calculated with different substrates were very similar, which confirms that the influence of the type of substrate on specific growth rate of a microorganism is not critical within a range.

Low inactivation constants $\left(\mathrm{k}_{\mathrm{D}}\right)$ of the different studied enzymes (Table 3) were also calculated. This fact has a biological basis. So, if the studied enzymes are secreted by fungi to be able to hydrolyse the substrate and then promote their growth, it would be expected that these enzymes maintain a certain resistance to deactivation in the conditions of the culture medium. Moreover, with enzymes with high inactivation rate, the fungus is forced to make more metabolic effort to keep enzyme activity when it is inactivated. What's more, mild conditions of fermentations have been used in this work (room temperature and neutral $\mathrm{pH}$ ) so, in general, these enzymes should show low inactivation rates.

More variability was obtained in the enzyme production constant $\left(\mathrm{k}_{\mathrm{E}}\right)$ (Figure 2). However, these results were expected given that certain microorganism can show an enzyme productivity when grows in a substrate, but that value may be different whether it grows in a different substrate or a different enzyme is being considered. Likewise, the same type of enzyme may be produced in different concentrations by different microorganisms, although all grow on the same substrate (Bailey and Ollis 1986). Consequently, the values of maximum enzyme productivity $\left(\mathrm{E}_{\mathrm{m}}\right)$ obtained in the different experiments performed in 
solid state fermentation in this work were different from each other. In this regard, it should be mentioned that some of the studied fungi were not able to grow in some used substrates, such as Trichoderma reseei or Aspergillus awamori on wheat straw. This fact also reinforces the idea previously mentioned about the minimum number of nutritional requirements needed for each microorganism to carry out fermentations on the available medium. So, a specific fungus may not grow if these minimum nutritional requirements are not contained on the substrate. On the contrary, if nutrients are available, it grows at its characteristic rate. Among all the studied substrates, orange peels are the most versatile, obtaining high enzyme productivities with all the studied fungi. However, if grape pomace is properly supplemented, enzyme productivity can increase in a $25 \%$.

A thorough comparison between the values of maximum time $\left(t_{\mathrm{m}}\right)$ obtained from the proposed equation, and the values from the numerical calculation, is shown in Table 4. Generally, results confirm that this equation reaches very good precision within the range of conditions used in this work, with errors bellow $5 \mathrm{~h}$, in more than 2 weeks fermentation processes. In addition to this, the proposed equation allows estimating the time of maximum enzyme activity for different combinations of microorganisms, substrate and enzymes. Consequently, the proposed kinetic model could be used with sufficient accuracy in the optimization of enzyme production by solid state fermentation in Petri dishes for a wide variety of fungus / substrate combinations.

\section{Ethical approval}

This article does not contain any studies with human participants or animals performed by any of the authors.

\section{Compliance with ethical standards \\ Conflict of interest}

The authors declare that they have no competing interest

\section{Acknowledgements}

The authors thank Spain Ministry of Science for the financial support of this study (CTQ2010-15452) and Herba Rice Mills and IFAPA center Rancho de la Merced to provide rice husk and wheat straw, respectively.

\section{References}

Bailey J, Ollis DF (1986) Biochemical Engineering Fundamentals. New York: McGraw-Hill. Barreto SM, Alzate CEO, Levin L (2011) Modeling Grifola frondosa fungal growth during solid-state fermentation. Eng Life Sci 11:316-321.

Biz A, Terezinha Jung A, Oliveira L, Schweitzer B, Krieger N, Mitchell D (2016) Production of pectinases by solid-state fermentation of a mixture of citrus waste and sugarcane bagasse in a pilot-scale packed-bed bioreactor. Biochem Eng J 111:54-62. 
Cadirci BH, Yasa I, Kocyigit A (2016) Streptomyces sp. TEM 33 possess high lipolytic activity in solid state fermentation in comparison with submerged fermentation. Prep Biochem Biotechnol 46:508-516. Castilho L, Polato C, Edmond A, Baruque E, Geraldo L, Sant'Anna Jr. G, Freire D (2000) Economic analysis of lipase production by Penicillium restrictumin solid-state and submerged fermentation. Biochem Eng J 4:239-247.

Diaz A, Caro I, de Ory I, Blandino A (2007) Evaluation of the conditions for the extraction of hydrolytic enzymes obtained by solid state fermentation from grape pomace. Enzyme Microb Tech 41:302-306. Diaz AB, Bolivar J, de Ory I, Caro I, Blandino A (2011) Applicability of enzymatic extracts obtained by solid state fermentation on grape pomace and orange peels mixtures in must clarification. LWT-FoodSci Technol 44:840-846.

Díaz AB, de Ory I, Caro I, Blandino A (2012) Enhance hydrolytic enzymes production by Aspergillus awamori on supplemented grape pomace. Food Bioprod Process 90:72-78.

dos Santos E, Piovan T, Roberto IC, Milagres AM. 2003. Kinetics of the solid state fermentation of sugarcane bagasse by Thermoascus aurantiacus for the production of xylanase. Biotechnol Lett 28:13-16. Durand A (2003) Bioreactor designs for solid state fermentation. Biochem Eng J 13:113-125. Favela-Torres E, Cordova-Lopez J, Garda-Rivero M, Gutirrrez-Rojas M (1998) Kinetics of growth of Aspergillus niger during submerged, agar surface and solid state fermentations. Process Biochem 3:103-107. Fernandes MLM, Saad EB, Meira JA, Ramos LP, Mitchell DA, Krieger N (2007) Esterification and transesterification reactions catalysed by addition of fermented solids to organic reaction media. J Mol Catal B Enzym 44:8-13.

Gupta SK. 1995. Numerical methods for engineers. New Delhi: New age international Ltd. Hashemi M, Mousavi SM, Razavi SH, Shojaosadati SA (2011) Mathematical modeling of biomass and alpha-amylase production kinetics by Bacillus sp in solid-state fermentation based on solid dry weight variation. Biochem Eng J 53:159-164.

Jian S, Ratna R, Sharma-Shivappa RR, Chinn MS (2012) Interactions between fungal growth, substrate utilization and enzyme production during shallow stationary cultivation of Phanerochaete chrysosporium on cotton stalks. Enzyme Microb Tech 51:1-8.

Jian S, Chinn MS, Ratna R. Sharma-Shivappa RR (2014) Interactions between fungal growth, substrate utilization, and enzyme production during solid substrate cultivation of Phanerochaete chrysosporium on cotton stalks. Bioprocess Biosys Eng 37:2463-2473.

Kapat A, Zimand G, Elad Y (1998) Biosynthesis of pathogenicity hydrolytic enzymes by Botrytis cinerea during infection of bean leaves and in vitro. Mycol Res 102:1017-1024.

Koopmans A, Koppejan J (1997) Agricultural and Forest residues - Generation, Utilization and Availability, Regional Consultation on Modern Applications of Biomass Energy, Kuala Lumpur, Malaysia. Kumar S, Sharma HK, Sarkar BC (2011) Effect of substrate and fermentation conditions on pectinase and cellulase production by Aspergillus niger NCIM 548 in submerged (SmF) and solid state fermentation (SSF). Food Sci Biotechnol 20:1289-1298.

Levenspiel O (1972) Chemical reaction engineering. New York: Wiley. 
Mazutti MA, Corazza ML, Maugeri F, Rodrigues MI, Oliveira JV, Treichel H, Corazza FC (2010) Hybrid modeling of inulinase bio-production process. J Chem Technol Biotechnol 85:512-519.

Miller GL (1959) Use of dinitrosalicylic acid reagent for determination of reducing sugar. Anal Chem 31:426-428.

Motta FL, Santana MHA (2014) Solid-State fermentation for humic acids production by a Trichoderma reesei strain using an oil palm empty fruit bunch as the substrate. App Biochem Biotechnol 172:2205-2217.

Motulsky H, Christopoulos A (2004) Fitting models to biological data using linear and non linear regression. New York: Oxford University Press.

Nampoothiri KM, Pandey A (1996) Solid state fermentation for L-glutamic acid production using Brevibacterium sp.Biotechnol. Lett 16:199-204.

Orzua MC, Mussatto SI, Contreras-Esquivel JC, Rodriguez R, de la Garza H Teixeira, JA, Aguilar CN ( 2009) Exploitation of agro-industrial wastes as immobilization carrier for solid-state fermentation. Ind Crop Prod 30:24-27.

Pandey A (1994) Solid state fermentation: an Overview. In: Pandey A, editor. Solid state fermentation. New Delhi:Wiley Eastern. p 3-10.

Pandey A. Nigam P. Vogel M (1988) Simultaneous saccharification and protein enrichment fermentation of sugar beet pulp. Biotechnol Lett 10:67-72.

Pandey A. Soccol CR (1998) Bioconversion of biomass: a case study of ligno-cellulosics bioconversions in solid state fermentation. Brazilian Arch Biol Technol 41:379-390.

Pandey A, Soccol CR, Nigam P, Soccol VT, Vandenberghe LPS, Mohan R (2000) Biotechnological potential of agro-industrial residues. II: Cassava bagasse. Bioresour Technol 74:81-87.

Raghavarao KSM, Ranganathan TV, Karanth NG (2006) Some engineering aspects of solid-state fermentation. Biochem Eng J 13:127-135.

Raimbault M, Germon JC (1976) Procédé d'enrichissement en protéines de produits comestibles solides, French Patent no. 76-06-677.

Roche N, Durand A (1996) Kinetics of Thermoascus aurantiacus solid-state fermentation on sugar-beet-pulppolysaccharidealteration and production of related enzymatic activities. Appl Microb Biotechnol 45:584588.

Rodríguez-Couto S (2008) Exploitation of biological wastes for the production of value-added products under solid-state fermentation conditions. Biotechnol J 3:859-870.

Rodriguez-Fernandez DE, Rodriguez-Leon JA, de Carvalho JC, Sturm W, Soccol CR (2011) The behavior of kinetic parameters in production of pectinase and xylanase by solid-state fermentation. Bioresour Technol 102:10657-10662.

Romo S, Gil I, Arévalo-Villena M, Briones A ( 2015) Production and immobilization of enzymes by solidstate fermentation of agro-industrial waste. Bioprocess Biosyst Eng 38:587-593.

Roopesh K, Ramachandran S, Nampoothiri KM, Szakacs G, Pandey A (2006) Comparison of phytase production on wheat bran and oilcakesin solid-state fermentation by Mucor racemosus. Bioresour Technol 97:506-511 
Ruiz HA, Rodriguez-Jasso RM, Rodriguez R, Contreras-Esquivel JC, Aguilar CN (2012) Pectinase production from lemon peel pomace as support and carbon source in solid-state fermentation columntray bioreactor. Biochem Eng J 65:90-95.

Ruíz-Leza HA (2004) Bioprocess development for pectinase production in solid-state fermentation using lemon peel pomace. Undergraduate Thesis, Food Research Department, School of Chemistry, Universidad Autónoma de Coahuila, Saltillo, Coahuila, Mexico.

Shah P, Gutierrez-Sanchez G, Orlando R, Bergmann C (2009) A proteomic study of pectin-degrading enzymes secreted by Botrytis cinerea grown in liquid culture. Proteomics 9: 3126-3135.

Shi J, Chinn MS, Sharma-Shivappa RR (2014) Interactions between fungal growth, substrate utilization, and enzyme production during solid substrate cultivation of Phanerochaete chrysosporium on cotton stalks. Bioprocess Biosyst Eng 37:2463-2473.

Singhania R, Patel AK, Soccol CR, Pandey A (2009) Recent advances in solid-state fermentation. Biochem Eng J 44:13-18.

Smits JP, Rinzema A, Tramper J, Van Sonsbeek HM, Knol W (1996) Solid-state fermentation of wheat bran by Trichoderma reesei QM9414: substrate composition changes, C balance, enzyme production, growth and kinetics. Appl Microbiol Biotechnol 46:489-496.

Umsza-Guez MA, Diaz AB, de Ory I, Blandino A, Gomes E, Caro I (2011) Xylanase production by Aspergillus awamori under solid state fermentation conditions on tomato pomace. Braz J Microbiol 42:15851597. 
Table 1. Regression coefficients $\left(\mathrm{R}^{2}\right)$ obtained after fitting experimental data to the proposed model at different studied conditions. Acronyms are defined in figures 1 and 2.

\begin{tabular}{|c|c|c|c|c|}
\hline ASP & XYL & EXO & CEL & \\
\hline GRA & 0.9592 & 0.9531 & 0.9874 & \\
\hline GRA+ & 0.9680 & 0.9165 & 0.9074 & \\
\hline ORA & 0.9857 & 0.9471 & 0.9810 & \\
\hline TRI & XYL & EXO & CEL & \\
\hline ORA & 0.9801 & 0.9461 & 0.9791 & \\
\hline RIC & 0.9430 & 0.9332 & 0.9327 & \\
\hline WHE & 0.9662 & 0.9160 & 0.9529 & \\
\hline PHA & XYL & EXO & CEL & \\
\hline ORA & 0.9690 & 0.9509 & 0.9668 & \\
\hline BOT & XYL & EXO & CEL & LAC \\
\hline GRA & 0.9559 & 0.9745 & 0.9476 & 0.9391 \\
\hline ORA & 0.9178 & 0.9022 & 0.9462 & 0.9304 \\
\hline RIC & 0.9009 & 0.9876 & 0.9541 & 0.9313 \\
\hline WHE & 0.9678 & 0.9795 & 0.9751 & 0.9499 \\
\hline
\end{tabular}


Table 2. Specific growth rate $(\mu)$ and confident limits $(\alpha=0.05)$ after fitting experimental data to the proposed model at different studied conditions $\left(10^{-3} \cdot \mathrm{h}^{-1}\right)$. Acronyms are defined in figures 1 and 2.

\begin{tabular}{|c|c|c|c|c|}
\hline ASP & XYL & $\mathrm{EXO}$ & CEL & \\
\hline$\overline{\text { GRA }}$ & $22.3 \pm 2.4$ & $34.8 \pm 2.6$ & $31.7 \pm 2.6$ & \\
\hline GRA+ & $38.3 \pm 3.5$ & $44.0 \pm 2.5$ & $35.8 \pm 2.6$ & \\
\hline ORA & $57.2 \pm 3.7$ & $37.9 \pm 2.7$ & $51.5 \pm 3.4$ & \\
\hline TRI & XYL & EXO & CEL & \\
\hline ORA & $86.2 \pm 5.4$ & $41.6 \pm 2.9$ & $36.6 \pm 3.1$ & \\
\hline RIC & $78.0 \pm 4.9$ & $48.4 \pm 5.1$ & $12.3 \pm 2.2$ & \\
\hline WHE & $36.0 \pm 5.4$ & $30.9 \pm 2.8$ & $33.6 \pm 3.1$ & \\
\hline PHA & XYL & EXO & CEL & \\
\hline ORA & $33.1 \pm 6.7$ & $20.2 \pm 6.5$ & $35.8 \pm 6.8$ & \\
\hline BOT & XYL & $\mathrm{EXO}$ & CEL & LAC \\
\hline GRA & $20.3 \pm 2.5$ & $44.2 \pm 4.1$ & $40.0 \pm 2.8$ & $75.8 \pm 5.1$ \\
\hline ORA & $15.6 \pm 2.5$ & $12.8 \pm 1.5$ & $17.1 \pm 2.6$ & $31.6 \pm 3.0$ \\
\hline RIC & $15.4 \pm 2.2$ & $44.2 \pm 6.2$ & $27.5 \pm 2.8$ & $24.7 \pm 3.4$ \\
\hline WHE & $39.4 \pm 3.1$ & $59.2 \pm 3.9$ & $36.1 \pm 3.1$ & $49.7 \pm 5.0$ \\
\hline
\end{tabular}


Table 3. Enzyme inactivation constant $\left(\mathrm{k}_{\mathrm{D}}\right)$ and confident limits $(\alpha=0.05)$ after fitting experimental data to the proposed model at different studied conditions $\left(10^{-3} \cdot \mathrm{h}^{-1}\right)$. Acronyms are defined in figures 1 and 2.

\begin{tabular}{|c|c|c|c|c|}
\hline ASP & XYL & EXO & CEL & \\
\hline GRA & $1.7 \pm 0.2$ & $<0.1$ & $0.5 \pm 0.1$ & \\
\hline GRA+ & $2.9 \pm 0.3$ & $2.8 \pm 0.2$ & $3.6 \pm 0.3$ & \\
\hline ORA & $2.2 \pm 0.1$ & $<0.1$ & $<0.1$ & \\
\hline TRI & XYL & EXO & CEL & \\
\hline ORA & $0.7 \pm 0.1$ & $<0.1$ & $0.2 \pm 0.1$ & \\
\hline RIC & $0.1 \pm 0.1$ & $22.1 \pm 2.3$ & $<0.1$ & \\
\hline WHE & $<0.1$ & $<0.1$ & $<0.1$ & \\
\hline PHA & XYL & EXO & CEL & \\
\hline ORA & $<0.1$ & $<0.1$ & $<0.1$ & \\
\hline BOT & $\mathrm{XYL}$ & EXO & CEL & LAC \\
\hline GRA & $<0.1$ & $0.3 \pm 0.1$ & $<0.1$ & $3.2 \pm 0.2$ \\
\hline ORA & $<0.1$ & $<0.1$ & $<0.1$ & $<0.1$ \\
\hline RIC & $<0.1$ & $4.8 \pm 0.7$ & $<0.1$ & $38.0 \pm 5.2$ \\
\hline WHE & $<0.1$ & $0.3 \pm 0.1$ & $<0.1$ & $3.2 \pm 0.2$ \\
\hline
\end{tabular}


Table 4. Time ( $\mathrm{t}_{\mathrm{m}}$ in hours) of maximum enzyme activity during the fermentation process calculated by numerical solution of the proposed model (left) and the approximate equation proposed (right) at the different studied conditions. Acronyms are defined in figures 1 and 2.

\begin{tabular}{|c|c|c|c|c|}
\hline ASP & XYL & EXO & CEL & \\
\hline GRA & $267.6-264.0$ & $>360$ & $235.6-235.7$ & \\
\hline GRA+ & $156.8-154.2$ & $140.6-138.4$ & $160.6-157.3$ & \\
\hline ORA & $115.4-114.4$ & $>360$ & $>360$ & \\
\hline TRI & XYL & EXO & CEL & \\
\hline ORA & $94.1-93.7$ & $>360$ & $229.0-228.4$ & \\
\hline RIC & $129.3-129.2$ & $93.5-90.1$ & $>360$ & \\
\hline WHE & $>360$ & $>360$ & $>360$ & \\
\hline PHA & XYL & EXO & CEL & \\
\hline ORA & $>360$ & $>360$ & $>360$ & \\
\hline BOT & XYL & EXO & CEL & LAC \\
\hline GRA & $>360$ & $187.9-188.0$ & $>360$ & $86.5-85.5$ \\
\hline ORA & $>360$ & $>360$ & $>360$ & $>360$ \\
\hline RIC & $>360$ & $128.5-126.0$ & $>360$ & $153.5-149.1$ \\
\hline WHE & $>360$ & $>360$ & $>360$ & $146.3-145.3$ \\
\hline
\end{tabular}


Figure 1. Activity of different enzymes (XIL: xilanase, EXO: exo-polygalacturonase, CEL: cellulose and LAC: laccase) over time during solid state fermentation (U/kg dry solid substrate) on different substrates (GRA: Grape pomace, GRA+: supplemented grape pomace, ORA: orange bagasse, RIC: rice husk and WHE: wheat straw).

A) Kinetic of enzymes production of Aspergillus awamori on different substrates

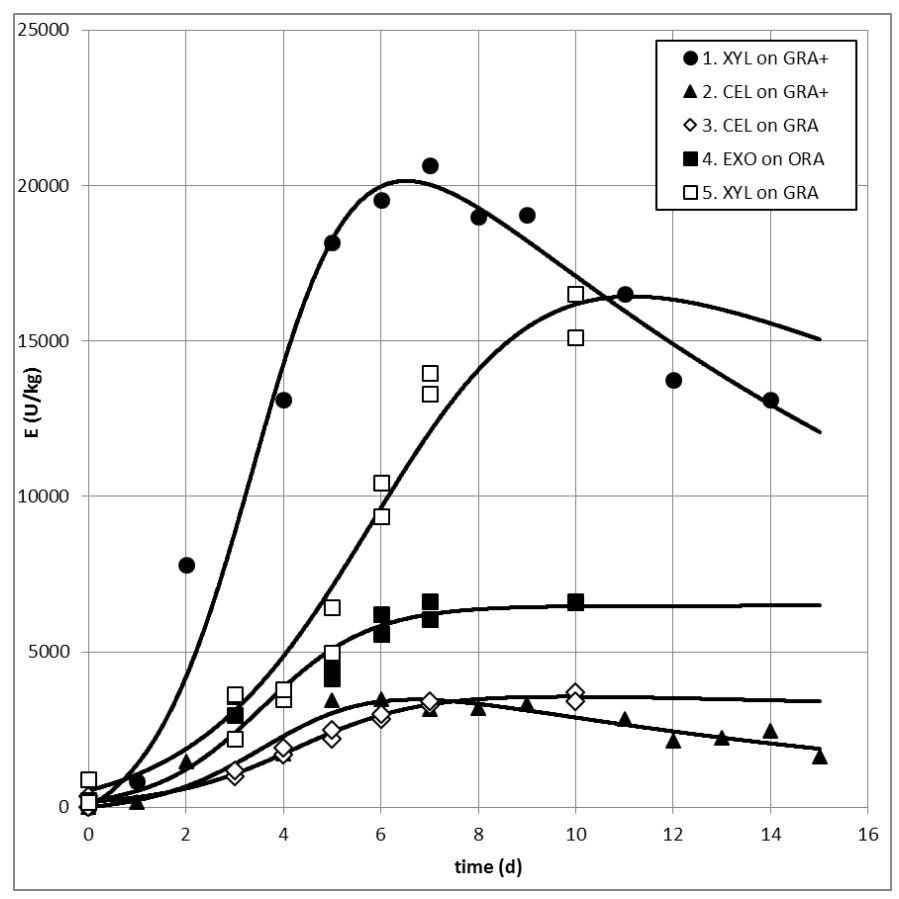

B) Kinetic of enzymes production of Botryotinia fuckeliana on different substrates

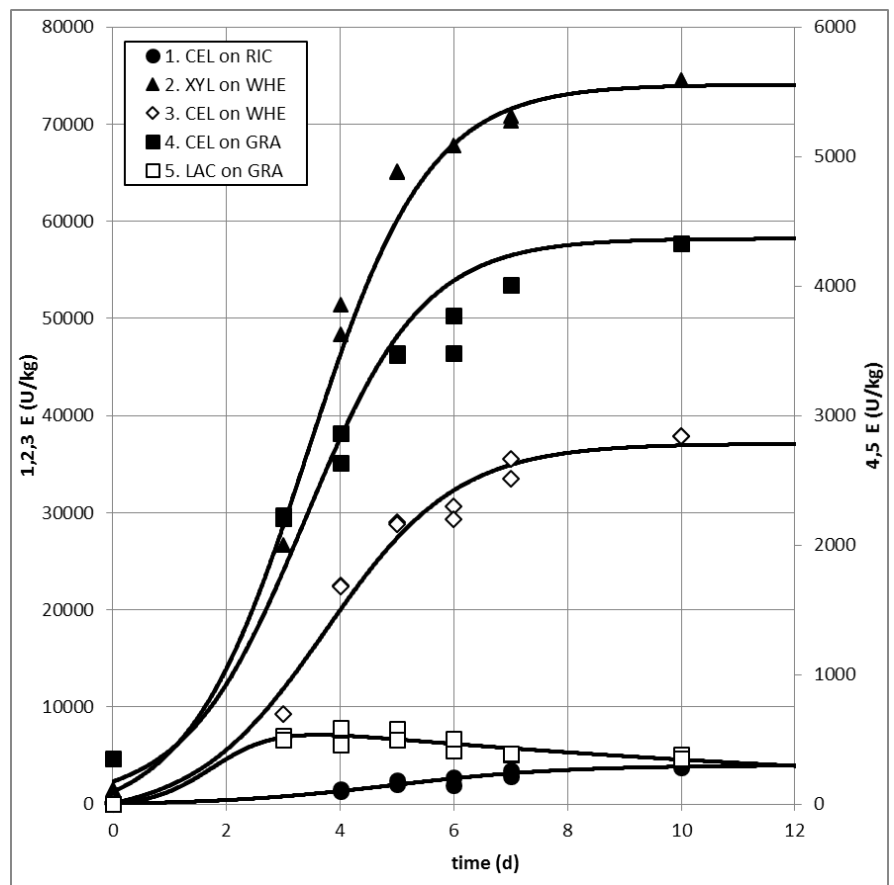


C) Kinetic of enzyme production of Tricholderma reesei and Phanerochaete chrysosporium on different substrates

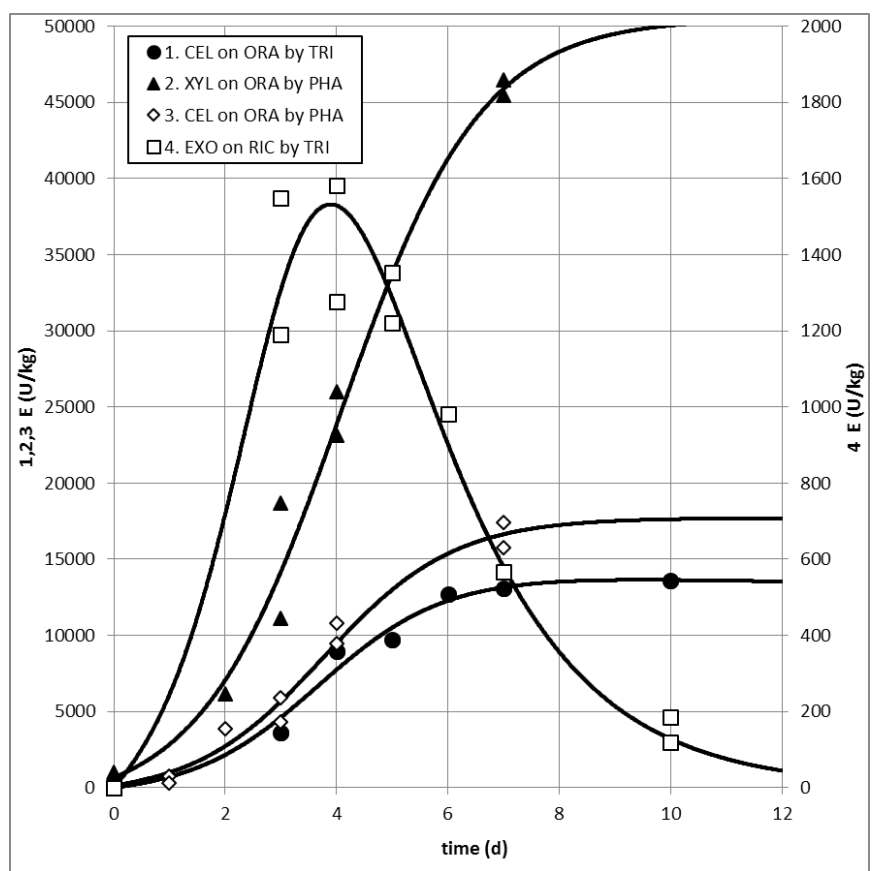


Figure 2. Microbial enzyme productivity constant $\left(\mathrm{K}_{\mathrm{E}}\right)$ for different enzymes, microorganisms and substrates (U/g dry solid). Solid state fermentations in all conditions were carried out in duplicate.

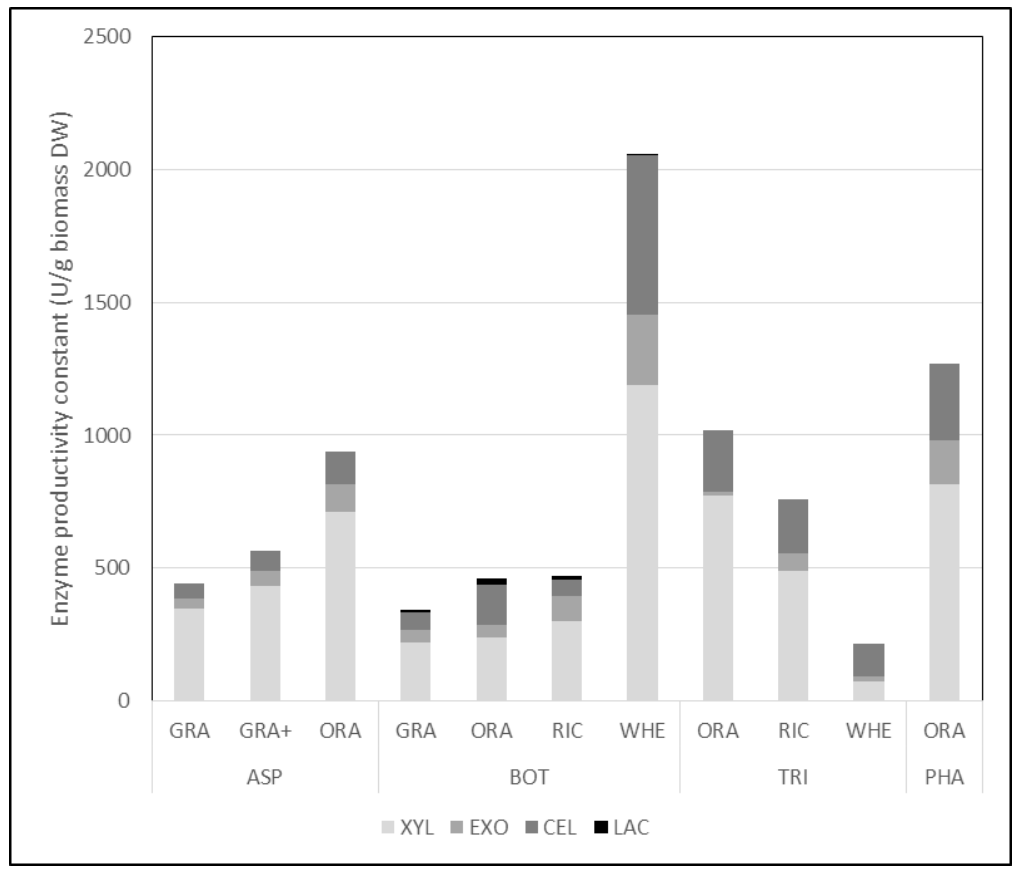

